\title{
Menjadi Guru Idaman Siswa
}

\author{
Mohammad Tohir \\ Mahasiswa S2 Pendidikan Matematika FKIP Universitas Jember \\ Guru SMP Negeri 2 Jember \\ Email: 160220101001@students.unej.ac.id
}

Peran Guru ketika disekolah sebagai orang tua bagi siswa. Dimana Guru harus berperan sebagai sosok panotan siswanya agar suasan belajar menjadi sesuatu yang menyenangkan dan sesuai dengan apa yang diharapkan. Siapa yang tidak mau menjadi guru yang diidamkan oleh siswa. Sepertinya semua guru akan mengharapkan hal ini. Akan tetapi tahukah kita bahwa semakin minta diidamkan siswa, maka akan semakin jauh kita dari kriteria guru yang layak diidamkani siswa? jika menjadi guru yang diidakan oleh siswa merupakan tujuan utama kita, maka sebagai guru tidak ada yang namanya profesionalisme lagi, yang ada hanyalah menuruti apa yang siswa mau dan yang diinginkan oleh siswa. Menjadi guru yang diidamkan oleh siswa juga bukan berarti menuruti semua yang siswa mau atau inginkan. Karena jika guru menuruti semua keinginan siswa bisa jadi malah membuat keluar dari tujuan dan kegiatan proses belajar mengajar.

Berikut adalah hasil survey dari pengalaman penulis tentang Guru yang diidamkan oleh siswa. Hasil survey ini didapat setelah upacara Hari Guru pada tanggal 25 November 2016 pagi ini.

1. Gurunya harus pinter, baik, seru, asik, ceria, pengertian, sering memberikan motivasi, lucu/suka bercanda, peduli, tegas, dan sabar.

2. Gurunya yang suka bercanda, tapi bercanda yang bermanfaat.

3. Menjelaskan dengan baik, menjelaskan pelajaran dengan bahasa yang mudah dipahami oleh siswa.

4. Menjelaskan dengan suara keras/lantang dan jelas sampai siswa paham.

5. Ketika Guru bertanya kepada siswa "Mengerti/paham anak-anak", kemudian siswa menjawab "Mengerti". Kadangkala siswa tersebut belum tentu sebenarnya belum mengerti. Jadi Guru harus peka.

6. Kalau mengajar tidak selamanya serius (fleksibel), tidak tegang, gak garing, tidak suka marah, tidak cuek, dan harus fun supaya "enjoy".

7. Tidak memukul siswa tetapi kalau siswanya salah tidak apa-apa.

8. Tidak mengatai siswanya bodoh.

9. Sering mengadakan kelompok belajar, tapi tidak selalu mengandalkan kerja kelompok.

10. Memberikan PR dengan jumlah yang sedikit dan tidak memberikan tugas yang membebani siswa.

11. Guru yang dapat memberikan PR kepada siswa berdasarkan kemampuan siswa.

12. Soal-soal ulangannya yang mudah dan sesekali ualngannya diganti tes lisan saja

13. Seharusnya bagi yang merasa kasar kepada siswanya mohon dihilangkan, karena sekolah itu adalah tempat yang menyenangkan bukan menjadi tempat yang menyeramkan.

14. Dapat membuat siswa tidak bosan dan tidak pilih kasih

15. Datang ke kelas tepat waktu

16. Sesekali gunakan permainan/game dalam belajar

17. Kalau ngajar yang ikhlas, jangan setengah-setengah

18. Kalau ngasih nilai jangan semaunya sendiri

19. Gurunya bisa menjadi sahabat siswa atau gurunya akran dengan siswa

20. Gurunya sering memberi motivasi dari pengalamannya

21. Harus bisa telaten kepada siswanya.

22. Memiliki aura menenangkan

23. Sering mengadakan kelas tambahan bagi siswa yang kurang paham. 
24. Sering memberikan soal cerita yang mudah dimngerti.

25. Guru yang dapat mengerti atas kemampuan siswa, kekurangan siswa, dan kelebihan siswa dalam belajar.

26. Guru yang tidak selalu mebandingkan antara siswa yang satu dengan siswa yang lainnya.

27. Menjelaskan ulang kalau ada siswa yang gak bisa atau belum paham.

28. Gurunya harus bijaksana.

29. Guru yang kalau menerangkan masuk ke otak dan dapat memastikan bahwa semua siswa sudah paham terhadap pelajaran yang dibahas.

30. Guru yang bisa membuat siswa menjadi lebih baik.

Berdasarkan hasil survey yang didapat oleh penulis, maka penulis dapat menyimpulkan bahwa menjadi Guru yang diidamkan oleh siswa adalah sebagai berikut:

1) Guru yang Menguasai Materi Pelajaran.

Mempersiapkan materi sebelum pembelajaran merupakan kewajiban mutlak yang harus dilakukan oleh seorang guru. Adanya persiapan yang matang akan mempengaruhi keberhasilan belajar.

2) Dalam mengajar Guru selalu mengunakan strategi pembelajaran aktif, inovatif, kreatif dan menyenangkan (PAIKEM).

Setiap materi memiliki cara penyampaiaan yang beragam. Guru jangan hanya terpaku dengan satu metode saja, misalnya hanya ceramah. Juga gunakan metode yang menyenangkan, yaitu yang membuat siswa aktif dan melakukan sendiri. Misalkan dengan menggunakan metode eksperimen/praktikum, dengan pengamatan langsung/pembelajaran alam sekitar, dengan metode cerdas cermat, dengan pembelajaran yang memakai alat bantu "audio-visual", dengan metode permainan atau game, dan lainlain.

3) Guru yang mampu memberikan motivasi belajar pada muridnya.

Pemberian dorongan untuk siswa dapat dilakukan pada saat penyampaian tujuan pembelajaran atau pada saat pertengahan pembelajaran atau diakhir pelajaran. Disaat itulah perlu disampaikan untuk apa dia mempelajari materi itu, dan apa kegunaannya dalam kehidupan sehari-hari. Agar siswa dapat memahami mamfaat langsung dari mempelajari materi tersebut. Apabila pada saat proses pembelajaran anak mengalami kelelahan dan kebosanan, ciptakanlah suasana menyenangkan.

4) Guru yang mampu menciptakan kondisi belajar mengajar yang kondusif

Proses belajar mengajar akan kondusif, jika Guru sudah menguasai materi pelajaran dan pastilah dalama menyampaikan materi tersebut dengan enak dan mudah dipahami oleh siswa serta guru tersebut akan dapat memberikan penilaian yang obyektif.

5) Menjadi guru yang humoris

Menjadi guru yang humoris merupakan salah satu syarat agar pembelajaran tidak membosankan. Karena pada pelajaran teretntu terkandang membutuhkan konsentrasi yang serius, disaat masalah terpecahkan perlu diselingi dengan cerita-cerita humor yang dapat mencairkan suasana. Hal ini akan terjadi jikalau seorang guru tersebut memiliki ketrampilan khusus dalam memunculkan gelak tawa siswanya.

6) Menyelengi pembelajaran dengan game.

Memberikan permainan atau game kepada siswa pada saat pembelajaran sangatlah dibutuhkan agar pembelajaran seperti bermain. Game disini digunakan untuk mengenalkan kepada siswa bahwa belajar matematika itu asik, kreatif, dan menyenangkan.

7) Guru yang memberikan hak dan kebutuhan muridnya.

Setelah terjadi proses mengamati, pengalaman belajar peserta didik berikutnya yang difasilitasi guru adalah pengalaman belajar menanya. Pengalaman belajar tersebut 
dimaknai sebagai menanya dan mempertanyakan terhadap hal-hal yang diamati. Terjadinya kegiatan 'menanya' oleh siswa dapat disebabkan oleh karena belum dipahaminya hal-hal yang diamati, atau dapat pula karena ingin mendapatkan informasi tambahan tentang hal-hal yang diamati. Agar proses menanya oleh peserta didik semakin hari berjalan semakin lancar dan berkualitas, guru dapat memfasilitasi dengan pancingan pertanyaan-pertanyaan yang berfungsi menggiring peserta didik untuk mempertanyakan hal-hal yang diamati.

8) Guru yang menjaga wibawa

Guru yang berwibawa akan tercermin dri tingkahlakunya atau sikapnya di dalam kelas atau di luar kelas.

9) Guru yang mampu menjadi contoh atau suri tauladan.

Menjadi contoh atau suri tauladan merupakan yang pertama dan utama sebagai seorang Guru. Katanya orang jawa Guru itu adalah digugu dan ditiru

10) Guru Memahami psikologi perkembangan anak.

Guru yang dapat memahami psikologi perkembangan anak dapat mengetahui sebab mengapa seorang siswa berbuat sesuatu, sehingga apabila siswa melakukan suatu kesalahan maka guru tersebut dengan cepat dan tanggap dapat mengubah siswa tersebut supaya beralih kepada perbuatan yang baik yang hendak dicapai dari tujuan pendidikan.

11) Guru yang Memahami Gaya belajar Anak.

Guru yang Memahami Gaya belajar Anak dapat menentukan gaya belajar yang dikuasai oleh siswa tertentu, sehingga setiap siswa dapat memahami setiap yang diajarkan oleh guru berdasarkan gaya belajar anak tersebut. Perlu kita ketahui kembali bahwa ada tiga jenis gaya belajar anak yang diantaranya adalah Audio, Visual dan kinestetik.

12) Guru yang selalu berpenampilan menarik dan murah senyum serta sabar.

Menjaga penampilan yang menarik bagi seorang guru merupakan suatu keharusan, karena kalau seorang guru berpenampilan menarik dan rapi akan membuat siswa merasa betah dengan guru. Apalagi kalau guru tersebut ditambah dengan murah senyum yang tulus kepada siswa, maka para siswa akan menyukai guru tersebut.

13) Guru yang mendidik dengan hati dan menginspirasi.

Mendidik atau mengajar bukan hanya dianggap sebagai pekerjaan atau profesi, lebih dari itu juga dimaknai sebagai pengabdian dan ibadah. Murid bukan hanya sebagai obyek, tetapi juga insan seperti anak, yang tidak hanya dididik juga didoakan.

14) Memberikan penghargaan kepada siswa

Pemberian penghargaan kepada siswa yang memiliki kuantitas dan kualitas pertanyaan investigatif yang baik. Dengan begitu, siswa mempersepsi kegiatan menanya sebagai suatu kegiatan yang bermanfaat. Menurut Imam Ghazali dalam kitab Ihya' Ulum ad-din menulis, "Jika pada seseorang anak menonjol akhlak baik dan perbuatan terpujinya, maka ia patut dimuliakan, digembirakan dan dipuji di depan orang banyak untuk memberikan semangat berakhlak mulia dan berbuat terpuji." Memuliakan anak dan memberi semangat dengan hadiah atau dengan ucapan yang manis sesuai dengan sabda Nabi yang diriwayatkan oleh ath-Thabrani, "Saling memberi hadiahlah agar kalian saling mencintai". Kalau kita perhatikan karakter siswa semasa sekolah, maka pastilah mereka sangat menyukai apabila dapat penghargaan dari gurunya, baik penghargaan yang sifatnya berwujud maupun tidak berwujud. Karena itu, seorang guru hendaknya merespons apa yang disukai seorang anak. Guru harus bisa memberikan hadiah-hadiah tersebut pada kesempatan yang tepat. 
15) Guru yang Up To date.

Guru yang Up To date dapat berkembang lebih cepat dari pada yang lain, karena guru yang mengajar dengan memiliki wawasan yang luas dan menggunakan cara-cara singkat dalam pemecahan masalah. Hal ini bisa diperoleh jika seorang guru terus mencari informasi-informasi terbaru. Misalnya saja, kemampuan analisis seorang guru dapat berkembang jika selalu berusaha memecahkan soal-soal yang sifatnya menalar

Mudah-mudahan dengan ulasan di atas, dapat menjadikan inspirasi bagi para guru di manapun berada. Apabila teman-teman Guru mempunyai pengalaman lain dengan yang telah diurakan di atas, maka akan lebih baik kalau kita selalu saling berbagi pengalaman dengan sesama. Agar proses belajar mengajar kita menjadi lebih bermakna.

\section{Pustaka}

Tohir, Mohammad. 2016. Menjadi Guru Idaman Siswa. Tersedia Online:

http://pasca.unej.ac.id/menjadi-guru-idaman-siswa/ [25 November 2016] 